\title{
LATE DEVONIAN PERALUMINOUS GRANITIC PLUTONS IN THE CANSO AREA, EASTERN MEGUMA TERRANE, NOVA SCOTIA*
}

\author{
J.D. $\mathrm{Hill}$ \\ Geological Survey of Canada \\ 601 Booth Street, Ottawa, Ontario K1A OE8 \\ present address: \\ Department of Mining Engineering \\ Technical University of Nova Scotia \\ P.O. Box 1000, Halifax, Nova Scotia B3J $2 \times 4$ \\ Date Received October 10, 1987 \\ Date Accepted January 10, 1988
}

\begin{abstract}
Late Devonian granitic rocks are well exposed in coastal outcrops near Canso in the eastern part of the Meguma Terrane. They form numerous, relatively homogeneous plutons of peraluminous biotite-muscovite granite and minor granodiorite which are enriched in muscovite. aluminum and alkalis and depieted in biotite and cafemic components relative to comparable rocks in other Meguma Terrane granites such as the South Mountain and Musquodoboit Batholiths. Individual plutons, which crystallized between 371 and $373 \mathrm{Ma}$ based on U-Pb isotopic data, show a variable relationship between composition and relative age of intrusion. This implies crystallization from two or more separate batches of slightly different magma supplied from below the current level of exposure. Highly felsic, peraluminous compositions and initial ${ }^{89} \mathrm{Sr} /{ }^{86} \mathrm{Sr}$ ratios ranging from 0.703 to 0.709 favour magma derivation from heterogenous intermediate to felsic continental crust containing some pelitic material. Intrusions were emplaced syntectonically during the early part of a ductile shearing event related to dextral transcurrent movements in the Cobequid-Chedabucto Fault System.
\end{abstract}

\begin{abstract}
Des roches granitiques tardidévoniennes forment de vastes affleurements 11ttoraux près de Canso. dans la partie orfentale de la Lanière de Méguma, où elles determinent des plutons nombreux relativement homogenes, constitués surtout de granites peralumineux à biotite et muscovite avec quelque granodiorite, qui sont enrichis en muscovite. aluminium, alcalis et deficitaires en biotite et composants cafemiques par rapport aux roches semblables des autres granites de la Laniere de Méguma tels que les batholites de South Mountain et de Musquodoboit. La methode U-Pb atteste d'une cristallization entre 371 et $373 \mathrm{Ma}$. La relation entre leur composition et l'age relatif de leur intrusion varie selon les plutons. On en dedult une cristallization a partir de deux (ou plus) venues magmatiques distinctes. 1egerement différentes et provenant d'un niveau sous-jacent a l'aff leurement actuel. Leur compositions distinctes, legerement differentes et provenant d'un niveau sous-jacent à $8{ }^{\prime}$ aff deurement actue 1 . Leur compositions
hautement felsiques et peralunineuses ains1 que des rapports initiaux $/ \mathrm{Sr} /{ }^{86} \mathrm{Sr}$ s'echelonnant de 0,703 a 0,709 permettent d'envisager come provenance magmatique la remobilisation d'une croate continentale heterogene, intermediaire a felsique, incorporant un apport pelitique quelconque. Les intrusions furent emplaces syntectoniquement durant l'amorce d'un eplsode de c1salllement duct1l relie a des mouvements transcourants dextres dans le systeme de fallles de Cobequid-Chedabucto.
\end{abstract}

[Traduit par le journal]

\section{INTRODUCTION}

A large amount of data has been published in recent years on peraluminous granitic plutons in the Meguma Terrane (e.g., McKenzie and Clarke, 1975; de Albuquerque, 1977; MacDonald, 1981). However, there is very little information available about intrusions in the Canso area, despite the fact that they probably offer the best exposure in all of the Meguma Terrane. This paper provides an interim report based on a two-year mapping project for the Geological Survey of Canada (Hill, in press). A brief summary of field relationships and compositions of granitic plutons in the Canso area is given and their age relationships and tectonic setting are discussed.

\section{GENERAL GEOLOGY}

The Canso area lies at the extreme eastern end of the Meguma Terrane, a suspect orogenic be1t separated from the Avalon Terrane to the north by \footnotetext{
30887

MARITIME SEDIMENTS AND ATLANTIC GEOLOGY

24. 11-19 (1988)

*Geological Survey of Canada Contribution No. the Cobequid-Chedabucto Fau1t System (Williams and Hatcher, 1982). The Canso area is underlain by the Cambro-Ordovician Meguma Group which is intruded by minor tonalite and numerous granitic plutons (Fig. 1). The Meguma Group is made up of a thick sequence of older psammitic (Goldenville Formation) and younger pelitic (Halifax Formation) sedimentary rocks interpreted as a continental embankment composed of coalescing deep-sea fans derived from western Europe or Africa (Schenk, 1978). Seismic data suggest that the Meguma Group was deposited on continental rather than oceanic crust (Dainty et al., 1966).

A few small bodies of peraluminous biotitg tonalite are preserved as xenoliths up to $0.3 \mathrm{~km}^{2}$ in area in younger granitic plutons east of Dover (Fig. 1). Preliminary evaluation of concordant U$\mathrm{Pb}$ zircon data indicates that one of the tonalite bodies crystallized at about $378 \pm 2 \mathrm{Ma}$ (T.E. Krogh, personal communication, 1987). Granitic rocks intruded both the Meguma Group and tonalite during the Late Devonian. They form numerous bodies ranging from miscellaneous dikes and xenoliths to plutons up to $40 \mathrm{~km}^{2}$ in area. The few contacts observed suggest that they are steep-walled. An east-west gravity profile calculated by $M$. Thomas 


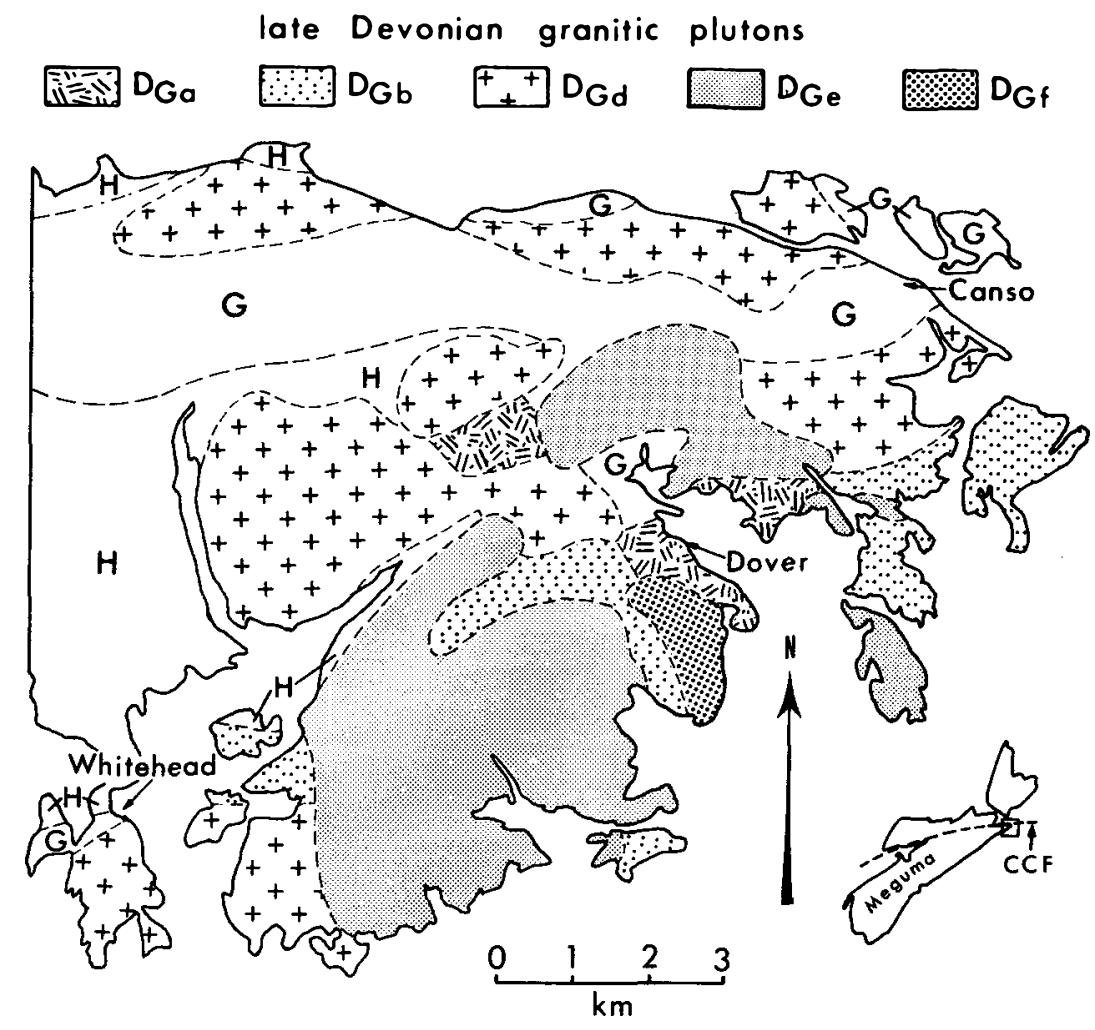

Fig. 1. Sketch map showing the distribution of the Cambro-Ordovician Meguma Group (G - Goldenville Formation; H Halifax Formation) and 18 Late Devonian granitic plutons (Units $D_{\text {fo }}$ to $D_{G f}$ ) in the Canso area. A few other plutons, including those in Unit $\mathrm{D}_{\text {a }}$ as well as Middle Devonian tonalite boodies, are too small to be shown. The Goldenville Formation in close proximity to some plutons includes agmatite formed by the injection of numerous dikes and lenses of aplitic to pegmatitic granite. Insert shows the location of the Canso area and the approximate trace of the CobequidChedabucto Fault System (CCF).

of the Geological Survey of Canada (personal communication, 1986) indicates that plutons in the southern part of the area extend to a maximum depth of about $3 \mathrm{~km}$. Agmatite is widespread north of Dover and east of Canso where the Goldenville Formation is intruded by numerous dikes and irregular lenses of aplitic to pegmatitic granite.

The eastern Meguma Terrane was deformed and metamorphosed during two main events. $D_{1}$, which is the dominant event throughout most of the Meguma Terrane, was caused by collision between the Meguma and Avalon Terranes during the Early Devonian (Schenk, 1978; Keppie, 1985). It produced east to northeast-trending, $\mathrm{km}$-scale, open to tight anticlines and synclines with subhorizontal axes. $D_{1}$ metamßrphism has been dated at $384-415 \mathrm{Ma}$ based on ${ }^{40} \mathrm{Ar} /{ }^{39} \mathrm{Ar}$ mica ages (Reynolds and Muecke, 1978; Dallmeyer and Kepple, 1987). The boundary between the Meguma and Avalon Terranes is marked by the Cobequid-Chedabucto Fault System. Movement assoclated with this fault system in the Middle to Late Devonian resulted in ductile shearing and subsequent brittle deformation $\left(D_{2}\right)$ along the northern margin of the eastern heguma Terrane (Kepple, 1985; Mawer and Williams, 1986). Kinematic Indicators point to an overail subhorizontal dextral sense of shear (Mawer and White, 1987). $D_{2}$ deformation may have been caused by post-accretionary adjustments and additional collisions among the outboard blocks in that part of the Appalachian Orogen (Williams and Hatcher, 1982; Keppie, 1985).

\section{PETROGRAPHY OF GRANITIC ROCKS}

Eighteen granitic plutons as well as numerous dikes, xenoliths and intrusions too small to show in Figure 1 have been recognized in the Canso area. Each pluton is relatively homogeneous in composition and texture compared to the total range of granitic rock types observed. In addition, interplutonic contacts are intrusive wherever seen in outcrop. Thus, the term "pluton," as used herein, refers to a body of granitic rock which, in most cases, is 11thologically distinct from its neighbours and appears to represent a single pulse of magma at the current level of exposure. The 18 plutons shown in Figure 1 , as well as four others too small to plot, are assigned to six units $\left(D_{\text {f }}\right.$ to $D_{G f}$ ) based on age relationships, composition and textufe. Units $D_{\text {(oldest) to }} D_{\text {(youngest) are }}$ inferred to repressent sequential emplacement of five batches of magma, each of which gave rise to more than one individual pluton (see below). The relative age(s) of Unit $D_{\text {f }}$ plutons is unknown. Brief descriptions of each unit are given in Table 1. Average chemical analyses, CIPW norms and modes of each unit are given in Table 2. Compositiona1 features are described in the following sections in terms of average unit and pluton compositions rather than individual rocks.

The granitic rocks are composed of only five essential minerals - quartz, biotite, muscovite, microcline, and plagioclase. Amphibole was not identified. Using a modified Streckeisen (1976) 
Table 1. Lithologic characteristics of the six granitic units recognized in the Canso area. Plagioclase compositions were determined by microprobe analysis in 25 samples, and represent both zoning in individual grains as well as inter-sample varlation.

Unit

Description

$D_{G a}$ - fine to medium grained leucogranite containing 2-3\% blotite and 9-12\% muscovite; equigranular except for a few small phenocrysts of microcline and mica. Plagioclase is $\mathrm{An}_{3-8}$.

$D_{G b}$ - very coarse grained, porphyritic to seriate granite and minor granodiorite with $5-8 \%$ biotite and $1-7 \%$ muscovite; characterized by 10-30\% microcline phenocrysts up to $15 \mathrm{~cm}$ long; cordierite(?) pseudomorphs and subsolidus sillimanite are common accessories. Plagioclase is $\mathrm{An}_{12-29}$.

$D_{G C}$ - fine grained porphyritic granite with $6 \%$ each of biotite and muscovite; contains $1-10 \%$ small phenocrysts of all essential minerals.

$D_{G d}$ - medium to medium-coarse grained granite with 2-9\% biotite and 4-14\% muscovite; generally equigranular except for a few oucrops containing small phenocrysts of microcline or muscovite; includes several plutons of unknown age which may not be correlative with this unit. Plagioclase is $A n_{1-14^{\circ}}$

$D_{\text {Ge }}$ - coarse grained, porphyritic to serlate granite with $6-7 \%$ biotite and 4-5\% muscovite; characterized by 1-20\% microcline phenocrysts up to 8 $\mathrm{cm}$ long; cordierite(?) pseudomorphs and subsolidus sillimante are common accessories. Plagloclase is $\mathrm{An}_{7-23^{\circ}}$

$D_{G f}$ - medium grained equigranular leucogranodiorite with $1 \%$ biotite and 10$12 \%$ muscovite. Plagioclase is $\mathrm{An}_{0-1}$.

plot in which albite is included with plagioclase, all of the average pluton modes are monzogranite except for three which plot in the granodiorite field close to the granite-granodiorite join (Fig. 2). Two of the granodiorite plutons (both Unit $D_{G f}$ ) contain plagioclase which is essentially pure albite. Thus, they are chemically akin to granite and would plot on the quartz-alkali feldspar foin if albite was included with microcline. These two plutons contain less than $1 \%$ biotite and are distinguished by the term leucogranodiorite. The remaining granodiorite pluton has the most calcic plagloclase found (1.e., An 1 ). Individual plutons have $1-9 \%$ biotite and $29-14 \%$ muscovite. Overa11, granit1c rocks in the Canso area are much more enriched in muscovite and depleted in biotite than other Meguma Terrane intrusions such as the Musquodoboit and South Mountain Batholiths (F1g. 3). Accessory minerals include apatite, monazite, zircon, ilmenite, garnet, tourmaline and sillimanite and rare allanite, sphene, spinel, fluorite, anatase and rutile. In addition, smectite aggregates inferred to be pseudomorphs after magmatic cordierite are common in some plutons in the southern part of the area.

The granitic rocks have been variably deformed by $D_{2}$ within $9 \mathrm{~km}$ of the northern margin of the Canso afea. As a result, all gradations between virtually undeformed granite and true mylonite with

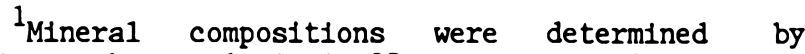
microprobe analysis in 25 granitic samples.
}

we11-developed S-C fabric are present. Unless otherwise noted, the following description is restricted to undeformed rocks which occur only in the southern half of the area. Undeformed granitic rocks range from fine- to very coarse-grained with medium-grained rocks being predominant. Coarse grained varleties are distinguished by the presence of microcline phenocrysts from $1-15 \mathrm{~cm}$ long. Phenocrysts locally define an impersistent subhorizontal magmatic follation and gentlyplunging 1ineation. Compositional layers similar to some of those described by Smith (1975) in the South Mountain Batholith are oriented parallel to the phenocryst follation in a few outcrops.

Although the undeformed rocks have relatively typical granitic textures in hand specimen, textural evidence in thin section indicates subsolidus recrystallization has occurred that is much more extensive than is typical of most granites with which the writer is familiar. Only plagloclase and accessory mineràls appear to partly preserve early magmatic textures. Microcline commonly protrudes into and replaces adjacent plagioclase grains. Muscovite and biotite form primary-1ooking subhedral laths as well as secondary grains which crosscut and replace both feldspars. Optical continuity and compositional homogeneity between adjacent primary and subsolidus-10oking micas indicate both types reequilibrated durlng the final stages of subsolidus crystallization. Acicular sillimanite grains crosscut all essential minerals without regard to crystal boundaries or structure. Subsolidus grains 
Table 2. Unweighted average anhydrous chemical analyses, CIPW norms and modal compositions of the six granitic units in the Canso area. Unit compositions were determined from 130 individual rock analyses. Modes were determined by counting 2500-10,000 points in several stained thin sections for each unit. They should be considered as approximate only. Modal data partis reflect both deuteric subsolidus and $D_{2}$ metamorphic crystallization. ac - accessory minerals. $\mathrm{N}^{2}$ - number of individual chemical analyses. $\mathrm{n}$ - number of plutons. $\%=$ aerial percentage of total granitic rocks in each unit.

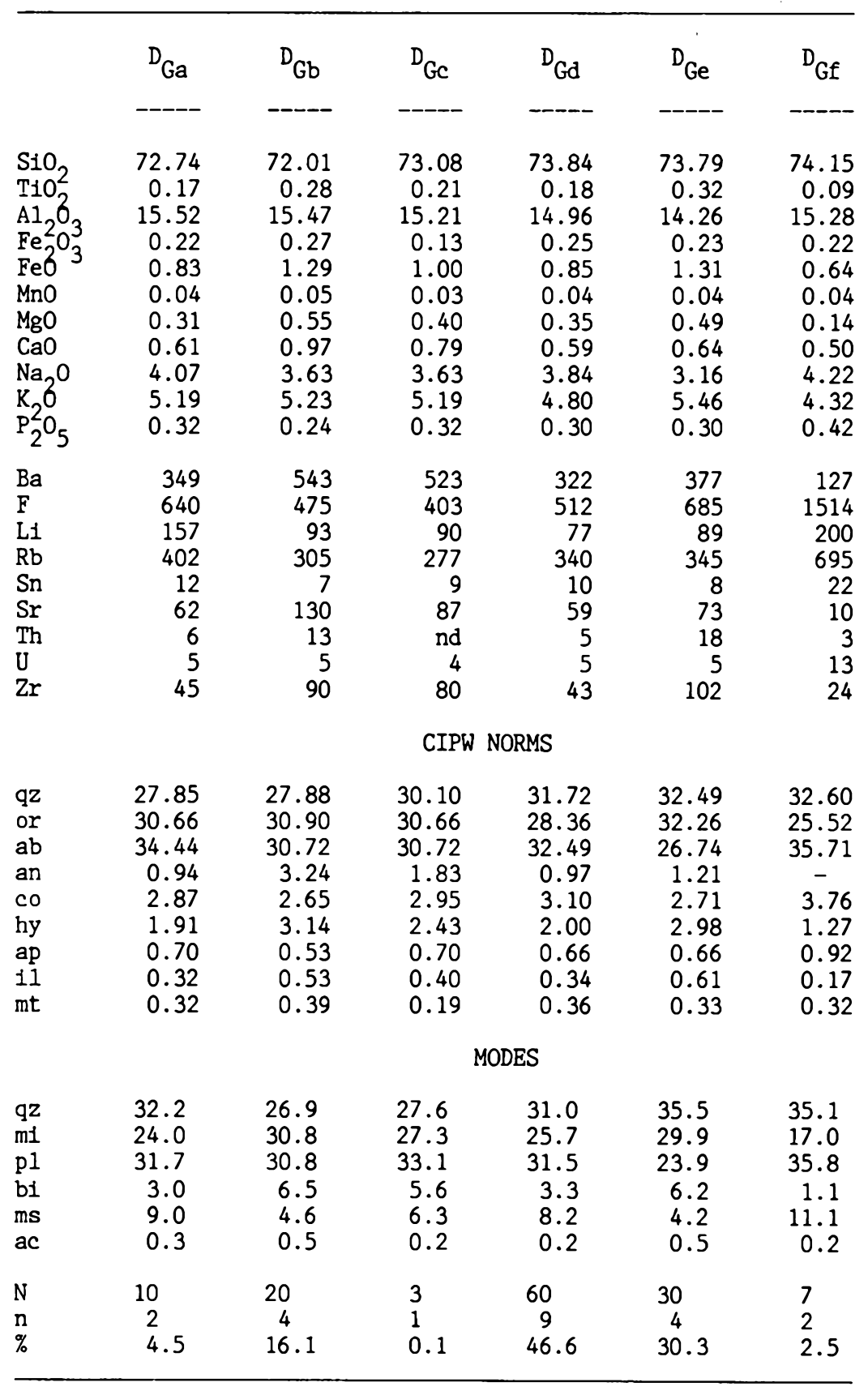




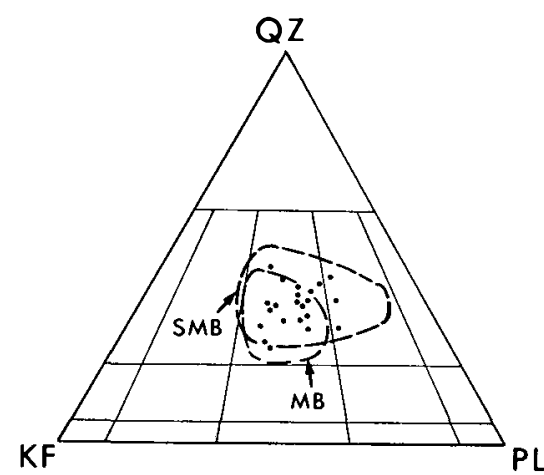

Fig. 2. Average modal compositions of the 18 granitic plutons shown in Figure 1 as well as four others in the Canso area which are too small to plot. Field boundaries are taken from Streckeisen (1976) except that plagioclase includes albite. The approximate ranges of the South Mountain Batholith (McKenzle and Clarke, 1975; Ham and Horne, 1986) and Musquodoboit Batholith (MacDonald, 1981) are shown for comparison.

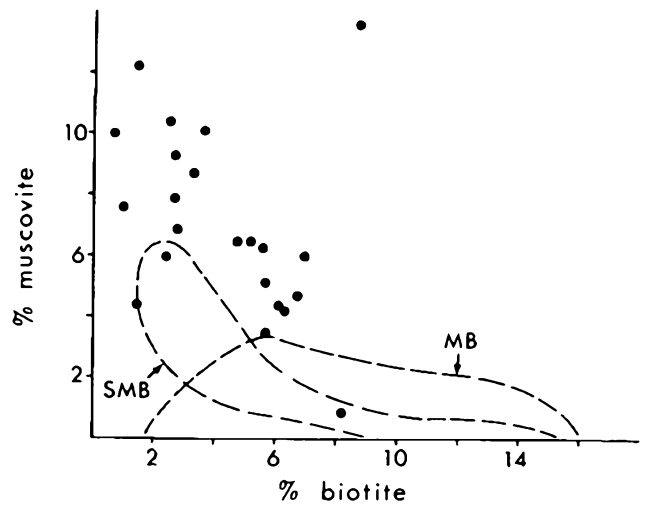

Fig. 3. Modal contents of biotite and muscovite in 22 granitic plutons in the Canso area. Symbols same as in Figure 2.

are deformed by post-granite ductile $D_{2}$ fabrics in the northern half of the Canso area. Since ductile $D_{2}$ deformation was closely related to granitic intrusion in time (see below), subsolidus crystallization in the undeformed rocks must have closely followed (and was probably continuous with) magmatic crystallization at near-magmatic temperatures.

\section{CHEMISTRY}

Average chemical compositions of the six granitic units are given in Table 2. Individual rock analyses from which unit averages were calculated are given in Hill (in press). Major elements were done by X-ray fluorescence by X-Ray Assay Laboratories Limited of Don Mills, Ontario. The use of a chrome steel $\mathrm{mill}$ for grinding has introduced an absolute error in $\mathrm{FeO}$ of $+0.05-0.15 \%$. Trace elements were done by a combination of wet chemistry and instrumental methods by Bondar-Clegg Company Limited of Ottawa, Ontario and X-Ray Assay Laboratories Limited. Precision is estimated at $\pm 0.5 \%$ (relative), $\pm 5 \%$ and $\pm 10 \%$ at the $70 \%, 1 \%$ and 100 parts per million levels of concentration, respectively.
Average pluton compositions given in Table 1 include analyses from both deformed and undeformed rocks. However, analysis of several deformed and undeformed samples from the same part of the same pluton suggests that $D_{2}$ deformation and metamorphism were essentially isochemical (Hill, in press). Each pluton is relatively homogeneous in composition and texture compared to the total range of granitic rock types observed. Compositional variation of individual samples in three plutons is compared to that for a11 Canso granitic rocks in Figure 4. Each pluton shows a specific range of compositions which is much less than the total range, even though they have similar $\mathrm{SiO}_{2}$ contents (see caption, Fig. 4). The 1ithologic homogeneity of each pluton suggests that average pluton and unit analyses give approximate compositions of the granitic magmas emplaced at the current level of exposure.

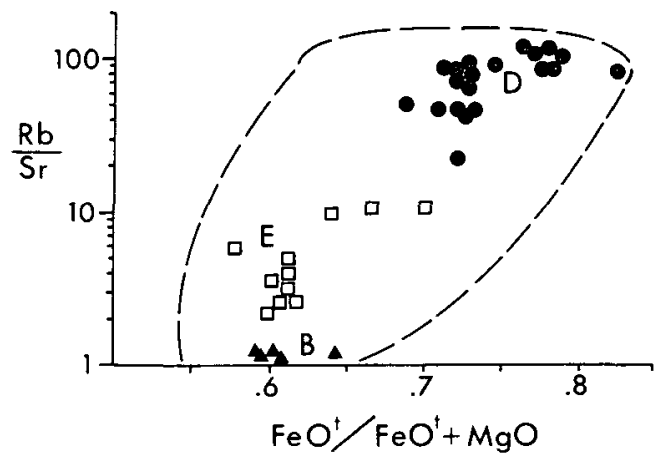

Fig. 4. Variation in $\mathrm{Rb} / \mathrm{Sr}$ and $\mathrm{FeO}^{t} / \mathrm{FeO}+\mathrm{MgO}$ (mole \%) within individual plutons compared to all granitic rocks in the Canso area. Capital letters designate the three plutons--one each from Units $D_{1}, D_{1}$ and $D_{1}$. Dashed line encompasses the total field for all granitic rocks in the Canso area. The three sets of samples partly overlap in SiO content, containing 70.0-72.2\% (B). 70.6$73.8 \%(E)$ and $33.4-75.3 \%$ (D).

Granitic plutons in the Canso area have a rather narrow compositional range, containing 70.7-75.6\% $\mathrm{SiO}_{3}$ and $0.1-0.8 \% \mathrm{MgO}$. All rocks are peraluminous, with normative corundum varying between $1.5 \%$ and $4.8 \%$. Selected major and trace elements are plotted in Figure 5. Inter-element correlation is good for some pairs (e.g., $\mathrm{FeO}$ and $\mathrm{MgO}$ ) and poor for others (e.g., $\mathrm{Al}_{2} \mathrm{O}_{3}$ and $\mathrm{MgO}$ ). The plutons have many but not all of the characteristics of S-type granites (see Chappe11 and White, 1974). They have high normative corundum, restricted compositional range and contain Al-rich minerals. On the other hand, compared to S-type granites in the Lachlan fold belt in Australia (Chappe11 and White, 1974), the Canso plutons have relatively high $\mathrm{Na}_{2} \mathrm{O}$ (2.9$4.4 \%)$ and low initial ${ }^{87} \mathrm{Sr} /{ }^{86} \mathrm{Sr}$ ratios ${ }^{2}(0.703-$ $0.709^{2}$ ).

\footnotetext{
${ }^{2} \mathrm{Rb}-\mathrm{Sr}$ isotopes were determined in eight whole rock samples by $R$. Theriault of the Geological Survey of Canada and initial ratios were calculated using a U-Pb monazite crystallization age of 372 Ma.
} 

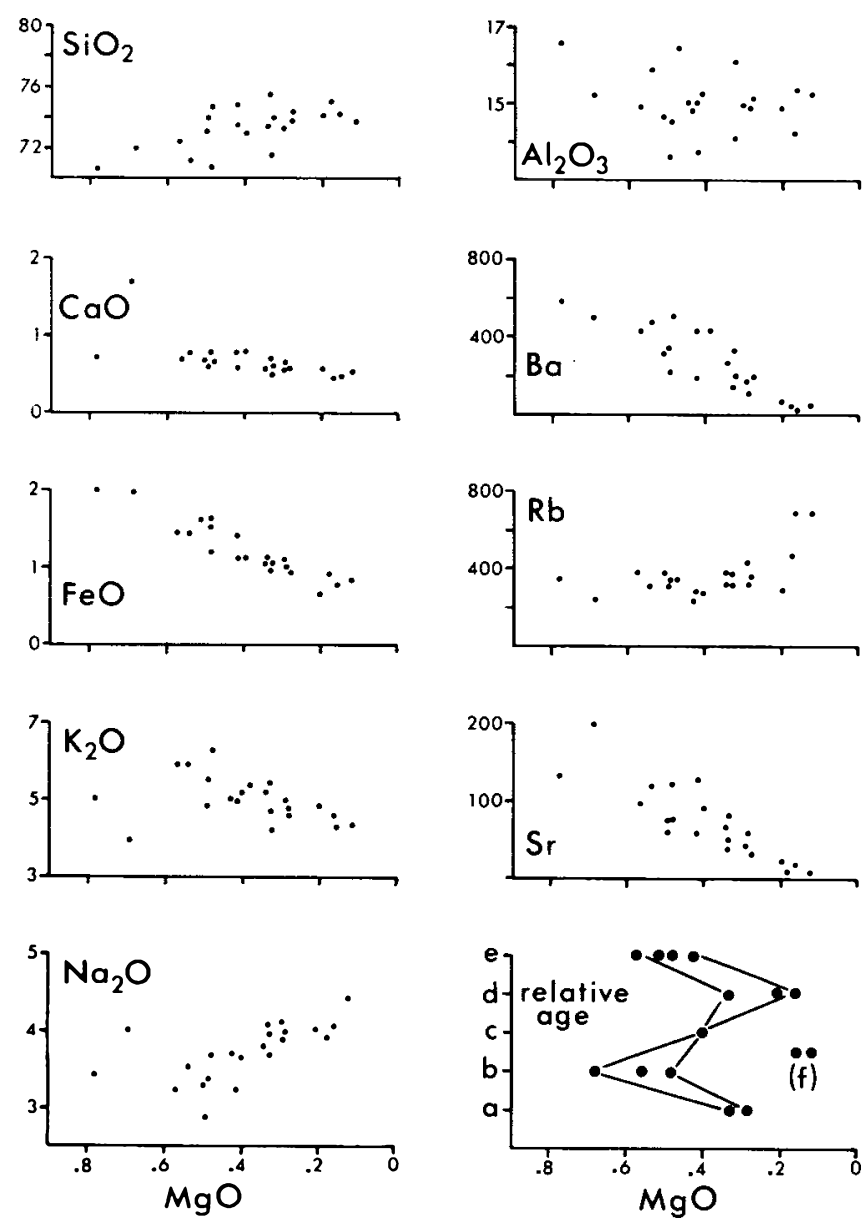

Fig. 5. Varlation diagrams for selected major and trace elements in 22 granitic plutons in the Canso area. Data are in weight $\%$ and ppm. The lower right diagram shows the varlation in $\mathrm{MgO}$ with relative age for plutons in Units $\mathrm{D}_{\mathrm{G}}$ to $\mathrm{D}_{\mathrm{Ce}}$, using only the 13 plutons with whol1y or partly known relative ages (see Fig. 7). Unit $D_{1}$ plutons (f), the relative ages of which are unknown, are plotted separately for comparison.

The Canso plutons are enriched in $\mathrm{Al}_{2} \mathrm{O}_{3}, \mathrm{Na}_{2} \mathrm{O}$. $\mathrm{K}_{2} \mathrm{O}$ and $\mathrm{Rb}$ and depleted in $\mathrm{FeO}, \mathrm{CaO}$ and $\mathrm{FgO}$ relative to comparable rocks in the South Mountain and Musquodoboit Batholiths. The South Mountain Batholith and Canso plutons are effectively distinguished by plotting $\mathrm{Al}_{2} \mathrm{O}_{3}+\mathrm{Na}_{2} \mathrm{O}+\mathrm{K}_{2} \mathrm{O}$ against $\mathrm{FeO}+\mathrm{MgO}$ ( $\mathrm{Fig}$. 6). ${ }^{2}$ The Musquodoboit Batholith falls at intermediate values. Average compositions of four other eastern Meguma Terrane plutons 1ie within the Canso field in Figure 6. This suggests that the chemical characteristics of granitic rocks in the Canso area may also be applicable to other plutons in the eastern Meguma Terrane. The most distinctive plutons of all are those belonging to Unit $\mathrm{D}_{\mathrm{ff}}$. They are muscoviterich and have high $\mathrm{F}, \mathrm{Li}$ and $\mathrm{Rb}$ and low $\mathrm{MgO}, \mathrm{Ba}, \mathrm{Sr}$ and $\mathrm{Zr}$. Their only counterpart farther west in the Meguma Terrane appears to be the East Kemptville leucogranite which has similar but more extreme chemical features (Kontak, 1987).

\section{RELATIVE AND ABSOLUTE PLUTON AGES}

Superb coastal outcrops in the southern and eastern parts of the Canso area have resulted in excellent exposure of a large number of interplutonic contacts. Contacts vary from simple and abrupt to agmatitic over large areas, and all those observed in the field are clearly intrusive. Partly or wholly known relative ages have been determined by dike-host-xenolith relationships for 13 plutons ( $\mathrm{Fig}$. 7). They resolve into a minimum of five episodes of intrusion (1.e., Units $D_{\text {no }}$ to $\left.D_{f e}\right)$ based on correlation of relative age With composition and texture. The two Unit $D_{\text {ff }}$ plutons of unknown age are assigned to their own unit because of their distinctive compositions. Seven other plutons have unknown relative ages and are correlated with Units $D_{G a}$ to $D_{G e}$ on the basis of 11thology only. Taking into account all of the plutons, including miscellaneous dikes and plutonic xenoliths which cannot be correlated with recognized units, requires at least six episodes of intrusion. This is only a minimum number--the sequence could be more complicated. The relationship between time of intrusion and $\mathrm{MgO}$

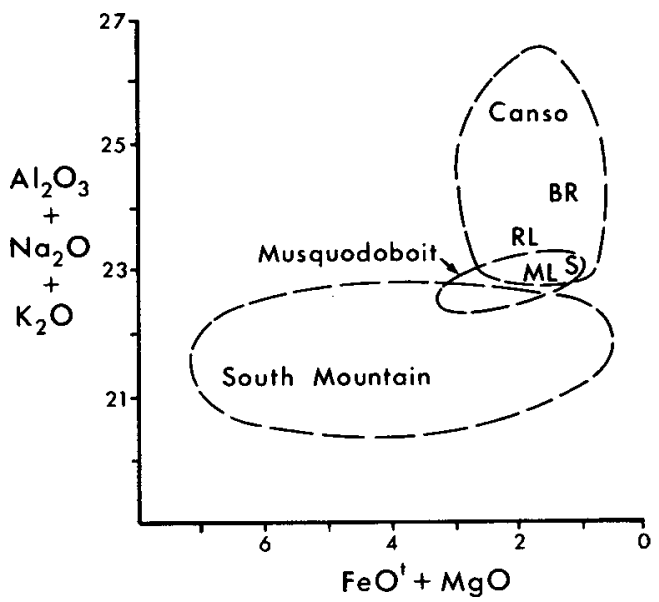

Fig. 6. Bivariate plot 1liustrating the differences between granitic plutons in the Canso area and comparable rocks in the South Mountain Batholith (Smith, 1974; McKenzie and Clarke, 1975) and Musquodobolt Bathollth (MacDonald, 1981). Average compositions of the Sherbrooke (S - Alizay, 1981), Bull R1dge (BR Chevalier, 1983). River Lake (RL - Thomas, 1982) and Mulgrave Lake (ML - Dwyer, 1975) plutons plot within the Canso fleld.

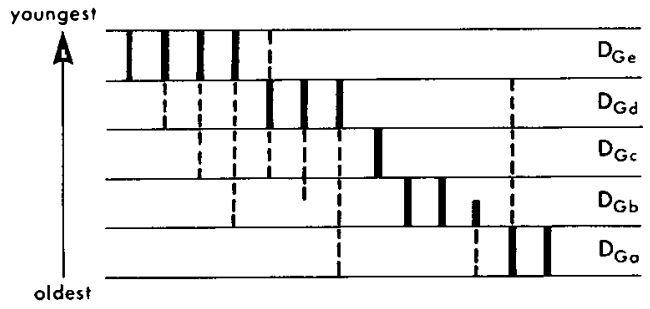

Fig. 7. Relative ages of intrusion of 13 granitic plutons in the Canso area. Thick vertical lines indicate inferred age and dashed lines indicate possible age range. The plutons are divided into five units ( $D$ to $D_{\text {f }}$ based primarily on relative age and secondarilfa on composition and texture. The relative ages of the remaining nine plutons, including those assigned to Unit $D_{G f}$, are unknown. 
content for the 13 plutons with partly or wholly known relative ages is shown in the lower right diagram in Figure 5. Clearly there is no simple correlation between relative age and composition. This relationship could become even more complex (but not less so) if relative ages of all plutons were known.

Three granitic plutons (assigned to Units $\mathrm{D}_{\mathrm{Ga}}$, $\mathrm{D}_{\mathrm{Gl}} 2077_{\mathrm{Pb} /}^{\text {and }} 235_{\mathrm{U}} \mathrm{D}_{\text {monazite ages of }}$ ) give concordant to almost and $372 \pm 1 \mathrm{Ma}$ respectively (Krogh, personal communication, 1987). These dates do not define an age sequence since they overlap within analytical uncertainty. Taking relative pluton ages into account implies that all intrusions in Units $D$ to

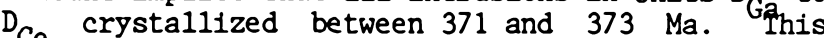
range may not cover the whole intrusive sequence since the ages of Unit $D_{G f}$ intrusions as well as miscellaneous dikes and plutonic xenoliths are unknown. However, age constraints on post-granite $D_{2}$ deformation (described below) suggest that all plutons were emplaced at approximately the same time. The short time span available for at least six episodes of granitic intrusion raises the possibility, indeed the probability, that magmas may have coexisted. However, no age reversals or evidence for magma mixing were observed in the fleld, although the latter would be difficult to detect because of similarity in pluton compositions.

\section{TECTONIC SETTING}

The granitic plutons were emplaced syntectonically after the beginning but during the early stages of $D_{2}$ dextral transcurrent shearing in the eastern Meguma Terrane. This deformation event has been described in some detall by Kepple (1985), Mawer and Williams (1986), Mawer and White (1987), H111 (In press), and H111 and Raeside (1987) and only a brief summary is given here. $D_{2}$ is comprised of a serles of overlapping phases of deformation and metamorphism that are believed to be part of a single progressive event. Three phases of initial ductile deformation $\left(D_{2 a}, D_{2 b}\right.$, $\mathrm{D}_{2 \mathrm{c}}$ ) have been recognized (H111, in press), each ${ }^{2} \mathrm{f}$ which produced transposition follation and Z-shaped folds (looking down plunge) of similar orientation (east to northeast-trending) and style. $D_{2}$ culminated with the formation of $10 c a 11 y$-developed crenulation cleavages and small open folds $\left(D_{2 d}\right)$ followed by low-temperature brittle deformation associated with development of a Riedel shear package of transcurrent faults and brittle-ductile shear zones $\left(D_{2}\right)$. Although overprinting relationships are obvious, Mawer and Williams (1986) have argued that separation into structural generations may not be useful in the Canso area since the evidence is compatible with a single event of progressive deformation. However, a sense of age progression is given by the fact that granitic intrusion occurred mainly between $D_{2}$ and $D_{\text {(see below) and that brittle structures }}$ invariably overprint ductile fabrics. For this reason, the concept of deformation phases (i.e., $D_{2 p}$, etc.) within a single progressive event (1.e., $D_{2}^{2} q^{\prime}$ is retained here.

${ }^{2}$ Granitic plutons truncate $D_{2}$ fabrics in the country rocks and are deformed $2 \mathrm{~g} \mathrm{D}_{2}$ and younger structures (see Fig. 2, H111 and Raeside, 1987).
This suggests that they were emplaced between $D_{2}$ and $\mathrm{D}_{2}$. However, two lines of evidence indicate that 2 Some plutons were still partly 11quid after the beginning of $D_{2}$ :

a) Aplite and pegmatite dikes associated with the granitic plutons are almost invariably deformed by $D_{2 b}$ structures. However, a few dikes in deformed agmatite east of Canso partiy crosscut $\mathrm{D}_{2 b}$ mesofolds and have locally intruded along $S_{2}^{2 b}$ cleavage planes oriented parallel to the axial surfaces of the folds.

b) Sillimanite fibers in two metasedimentary hornfels xenoliths in a granite pluton $2 \mathrm{~km}$ southwest of Dover define a faint schistosity. Although the adjacent granite is not recognizably deformed, the schistosity in the xenoliths is concordant with $S_{\text {b }}$ observed in deformed granite $1 \mathrm{~km}$ to the north. This suggests that the sillimanite, which probably crystallized in response to contact metamorphism, developed preferred orientation in a weak $D_{2 b}$ stress field.

The older age limit of $D_{2}$ is given by tonalite which occurs as xenoliths in granite $2-4 \mathrm{~km}$ east of Dover. In general, $D_{2 b}$ fabric crosscuts both tonalite and granite wilhout regard to contacts. But a different relationship was observed in one outcrop where the effects of $D_{2 b}$ are only barely visible. There, angular tonalite xenoliths with an obvious mylonitic foliation are variably oriented within a granite intrusion (Fig. 8). A weak1y developed east-trending $D_{2 b}$ follation is present in the granite. The follation in the xenoliths must have formed after crystallization of the tonalite at ca. $378 \mathrm{Ma}$ and prior to intrusion of the granite at ca. $372 \mathrm{Ma}$. Since $D_{1}$ has been dated at 384-415 $\mathrm{Ma}$ (Reynolds and Muecke, 1978; Dallmeyer and Keppie, 1987), the fabric in the tonalite appears to be related to $D_{2 a}$. This places a maximum age of about $378 \mathrm{Ma}$ on $\mathrm{D}_{2}{ }^{2 a}$ The younger age limit of $\mathrm{D}_{2}$ is provided by the Early Carboniferous (Tournasian) Horton Group which oversteps part of the CobequidChedabucto Fault System and Meguma Terrane 200-300 $\mathrm{km}$ west of the Canso area (Be1t, 1968). Horton Group fanglomerates, which are coarsest and most abundant along the fault contact with the Meguma Terrane, contain Meguma-derived clasts which have apparent $D_{2}$ fabrics and which were metamorphosed to at least upper greenschist facies prior to erosion (e.g., Keppie, 1985; Hill, in press). These relationships indicate that the ductile phases and possibly much of the brittle phase of $D_{2}$ were complete by $350-360 \mathrm{Ma}$. Thus, $\mathrm{D}_{2}$ dextral shearing occurred between 378 and $350-360 \mathrm{Ma}$. This age range is in agreement with isotopic dates of 362$373 \pm 7$ Ma for porphyroblasts and mica related to $D_{2}$ in the eastern Meguma Terrane (Dallmeyer and Keppie, 1984) as well as 371-373 Ma for granitic plutons in the Canso area (this report).

\section{DISCUSSION}

The Canso area is underlain by 18 granitic plutons larger than $0.2 \mathrm{~km}^{2}$, each of which is relatively homogeneous in 11thology compared to the total range of rock types observed. They, as well as numerous smaller bodies, are composed of biotite-muscovite granite and minor granodiorite which plots close to the granite-granodiorite boundary. They formed by the intrusion of at least six separate pulses of magma at ca. $372 \mathrm{Ma}$. 


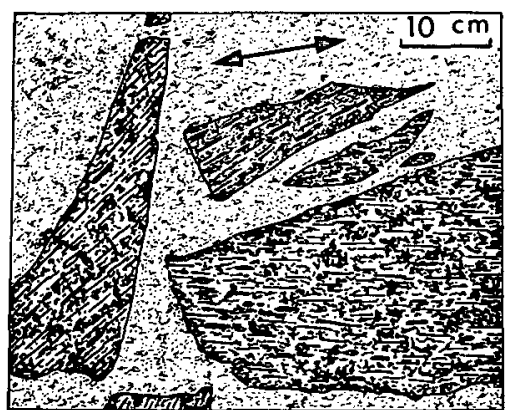

Fig. 8. Angular tonalite xenoliths (dark) are enclosed in granite $4 \mathrm{~km}$ east of Dover in the Canso area. Note the variable orientation of the mylonitic follation in the xenoliths compared to the weakly-developed $D_{2 b}$ follation (parallel to arrow) in the granite.

Detalled analysis of the petrogenesis of the granitic plutons is beyond the scope of this paper. However, the lack of simple correlation between pluton chemistry (e.g., $\mathrm{MgO}, \mathrm{Ca} / \mathrm{Na}$, etc.) and relative age of intrusion suggests that the mode1 of a single cogmatic suite of rocks related by in situ fractional crystallization of a uniform parent, as has been inferred for the South Mountain Batholith (McKenzie and Clarke, 1975), is not app11cable. Instead, a supply of magma that varled irregular1y in composition with time must have been avallable below the current level of exposure. The highly felsic, peralumigous compositions and wide range in initial ${ }^{87} \mathrm{Sr} /{ }^{86} \mathrm{Sr}$ ratios $(0.703-0.709)$ suggest that the most plausible mechanism involved two or more different batches of magma generated at about the same time in a heterogenous source of intermediate to felsic continental crust containing some proportion of pelitic material. However, processes such as restite unmixing, variable accumulation of early-formed crystals or perlodic replenishment of an underlying chamber with a uniform magma composition cannot be totally discounted at this time with the data available. In this regard, zircons in some of the granitic plutons contain rounded cores typical of Inheritance (Krogh, personal communication, 1987). The relative1y $10 \mathrm{w}$ initial ${ }^{8} \mathrm{Sr} /{ }^{86} \mathrm{Sr}$ ratios compared to many S-type granites suggests that the source material was low in rubidium and/or had a short residence time in the crust.

The plutons were emplaced syntectonically after the beginning but during the early stages of $D_{2}$ ductile shearing assoclated with dextral transcurrent movements along the CobequidChedabucto Fault System. The presence of tonalite. which has 11quidus temperatures of $1000-1100^{\circ} \mathrm{C}$, suggests that mafic magma may have been involved in some way-- either by supplying heat or by giving rise to the tonalite plutons directly (Wyllie, 1977). Tonalite intrusion temperatures could have been much lower if they were restite or cumulaterich mushes. However, a restite origin is partly opposed by the fact that zircons in the tonalites are clear, euhedral and lack inherited cores (Krogh, personal communication, 1987). No other igneous rocks of different composition are associated in time with the tonalite so a cumulate origin is not favoured either. Thus, crustal thickening during $D_{1}$ and $D_{2}$ possibly augmented by uprise of mafic magna is believed to be the most 11kely heat source for the generation of the granitic magmas. A period of amphibolite-grade stat1c metamorph1sm (Keppie, 1985), which is not obviously related to in situ contact metamorphism, occurred at about the same time as granitic plutonism (H111 and Raeside, 1987). Under the scenario outlined here, both static metamorphism and granitic plutonism were caused by the same thermal event (see also Kepple, 1985). Metamorphic mineral assemblages in the granitic plutons and metasedimentary country rocks suggest that the current level of exposure represents intrusion at depths of 10 to $13 \mathrm{~km}$ (Raeside et al., this volume; Hi11, in press).

\section{ACKNOWLEDGEMENTS}

This report is based on work done under the Canada-Nova Scotia Mineral Development Agreement of 1984-1989. T. Krogh of the Royal Ontario Museum and $R$. Therlault of the Geological Survey of Canada completed all 1sotopic work. The manuscript has benefitted from reviews by J.B. Whalen, S.M. Barr and D.J. Kontak.

ALIZAY, K.M. 1981. Zur geologle und geochemie des Sherbrookeplutons, Nova Scot1a, Kanada. M.Sc. thes1s, University of Hamburg, Hamburg, West Germany, 107 p.

BELT, E.S. 1968. Post-Acadlan rifts and related facies, eastern Canada. In Studies of Appalachian Geology. Edited by E-An Zen, W.S. White, J.B. Hadley and J.B. Thompson. Interscience, New York, pp. 95-113.

CHAPPEL1, B.W., and WHITE, A.J.R. 1974. Two contrasting granite types. Pacific Geology, 8, pp. 173-174.

CHEVALIER, B.A.M. 1983. Petrography and geochemistry of the Bul1 R1dge pluton, Guysborough County, Nova Scotia. B.Sc. thesis, Acadia University, Wolfville, Nova Scot1a, 104 p.

DAINTY, A.M. KEEN C.E. KEEN M.J. and BLANCHARD, J.E. 1966 Review of geophysical evidence on crust and upper-mantle structure on the eastern seaboard of Canada. In The Barth Beneath the Continents. Edited by J.S. Steinhart and T.J. Smith. American Geophysical Union, Monograph Number 10, pp. 349-369.

DALLMEYER, R.D. , and KEPPIE, J.D. 1984. Geochronological constraints on the accretion of the Meguma Terrane with North America. In Geological Society of America, Abstracts with Programs, 16, p. 11.

DALLMEYER R.D. and KEPPIB, J.D. 1987. Polyphase 1ate Paleozolc tectonothermal evolution of the squthwestern Meguma Terrane, Nova Scotia: evidence from ${ }^{40}$ Ar/ ${ }^{39}$ Ar mineral ages. Canadian Journal of Earth Sclences, 24, pp. 1242-1254.

de ALBUQUERQUB, C.A.R. 1977. Geochemistry of the tonalitic and granitic rocks of the Nova Scotia southern plutons. Geochimica et Cosmochimica Acta, 41, pp. 1-13.

DWYER, G.J. 1975. Petrology of the Mulgrave Lake adamel11te pluton. B.Sc. thesis, Dalhousie University, Halifax, Nova Scotia.

HAM, L.J. and Horne, R.J. 1986. Geology of the South Mounta1n Bathollth on the eastern half of NTS Map Sheet 21A/16. In Mines and Minerals Branch, Report of Activities. Bdited by J.L. Bates. Nova Scotia Department of Mines and Energy. Report 86-1. pp. 149-159.

HILL, J.D. In press. Geology of the Canso and Forest H111 area, eastern Meguma Terrane, Nova Scot1a, with emphasis on the petrology, tectonic setting and economic potentlal of Devonian peraluminous granitold plutons. Geological Survey of Canada Bulletin.

HILL, J.D., and RAESIDE, R.P. 1987. D1scussion of 'structural study of highly deformed Meguma phyllite and granite, vicinity of Wh1te Head V1llage, S.E. Nova Scot1a' by C.K. Mawer and P.F. Williams. Maritime Sediments and Atlantic Geology. 23. pp. $151-154$

KEPPIE, J.D. 1985. Geology and tectonics of Nova Scotia. In Appalachians Geotraverse (Canadian Ma1nland). Geological and Mineralogical Associations of Canada Annual Meeting. Gu1debook to Excursion 1, pp. 23-108.

KONTAK, D.J. 1987. The East Kemptville leucogranite: a possible mid-Carboniferous topaz granite. In Mines and Minerals Branch, Report of Activities 1986. Bdited by J.L. Bates and D.R. MacDonald. Nova Scotia Department of Mines and Energy. Report 87-1. pp. 81-94. 
MACDONALD, M.A. 1981. The mineralogy, petrology and geochemistry of the Musquodobolt Batholith. M.Sc. thesis Dalhousle University, Hallfax, Nova Scot1a, $272 \mathrm{p}$.

MAWER, C.K., and WHITB, J.C. 1987. Sense of displacement on the Cobequid-Chedabucto fault system. Nova Scotia, Canada. Canadian Journal of Earth Sciences, 24, pp. 217-223.

MAWER, C.K., and WILLIAMS, P.F. 1986. Structural study of highly deformed Meguma phyllite and granite, vicinity of White Head Village, S.E. Nova Scotia. Maritime Sediments and Atlant1c Geology, 22, pp. 51-64.

MCKENZIE, C.B. and CLARKE, D.B. 1975. Petroloy of the South Mounta1n Bathol1th, Nova Scot1a. Canadian Journal of Earth Sciences, 12, pp. 1209-1218.

RAESIDE, R.P., HILL, J.D. , and EDDY, B.G. 1988. Metamorph1sm of Meguma Group metasedimentary rocks. Whitehead Harbour area Guysborough County, Nova Scotia. Mar1time Sediments and Atlant1c Geology, 24, pp. 1-9.

REYNOLDS, P.H. and MUECKE, GgK. 1978. Age studies on slates: applicability of the ${ }^{40} /{ }^{39}$ stepwise outgassing method.
Earth and Planetary Sclence Letters, 40, pp. 111-118.

SCHENK P.B. 1978. Synthesis of the Canadian Appalachians. Geological Survey of Canada, Paper 78-13, pp. 111-136.

SMITH, T.E. 1974. The geochemistry of the granit1c rocks of Halifax County. Nova Scot1a. Canadian Journal of Earth Sc1ences, 11, pp. 650-657.

SMITH, T.B. 1975. Layered grantit1c rocks at Chebucto Head, Halifax County. Nova Scotia. Canadian Journal of Earth Sclences, 12 , pp. 456-463.

STRECKEISEN, A. 1976. To each plutonic rock 1ts proper name. Earth-Sclence Reviews, 12, pp. 1-33.

THOMAS, W.C. 1982. Petrology and geochemistry of the R1ver Lake pluton. Halifax County. Nova Scotia. M.Sc. thesis, Acadia University. Wolfville, Nova Scot1a, $133 \mathrm{p}$.

WILLIAMS, H. . and HATCHER, R.D. 1982. Suspect terranes and accretionary history of the Appalachian orogen. Geology. 10. pp. $530-536$

WYLLIE, P.J. 1977. Crustal anatex1s: an experimenta1 review. Tectonophysics, 43 , pp. 41-71. 